\title{
Comparative Studies of Forage Yield and Quality Traits among Proso Millet, Foxtail Millet and Sainfoin Varieties
}

\author{
Sadegh Mohajer, Rosna Mat Taha, Arash Khorasani, and Elnaiem Elaagib Mubarak
}

\begin{abstract}
In order to compare variation and relations among yield and quality traits of three forage species, 9 superior varieties of sainfoin (Onobrychis sativa), proso millet (Panicum miliaceum) and foxtail millet (Setaria italica), were assessed using complete block design with three replications. Results of ANOVA showed significant differences $(p<0.01)$ among species in all factors. Although, the highest average values of 14.37 and 8.23 ton $\mathrm{ha}^{-1}$ Dry Matter (DM) yield were obtained for the foxtail and proso millet, respectively, sainfoin was significantly premier in important traits such as crude protein, dry matter digestibility and crude fiber. Combined phenotypic correlation between DM yield with both water soluble carbohydrates and crude protein were negatively significant, whereas its relationship with crude fiber was negative. Using principal component analysis, the first four independent components with values more than 1.0 accounted for $91 \%$ of total variation. Based on ward cluster analysis, 9 varieties were divided into 3 groups. Totally, distribution of populations on the first two component scores was in agreement with cluster analysis.
\end{abstract}

Index Terms-Forage yield, quality traits, correlation, PCA and cluster analysis.

\section{INTRODUCTION}

Fodder crops play pivotal role in the agricultural economy of developing countries by providing cheapest source of feed for livestock. The evaluation of novel forages in new growing environments involves assessment of forage establishment, including morphological factors, dry matter yield and quality characterization [1]. Because of the variation in nutrient concentrations in plant tissues, herbivores forage selectively to meet their nutritional requirements [2], and forage quality has consequences for the survival and reproductive success of herbivores [3]-[5].

Information on quality traits studies of forage species is still rare in comparison to the increasing number of options of forage plants and also because of the difficulty on knowing each plant through pasture trials [6]. Traditional agronomic attributes of particular interest to livestock producers include herbage yield and quality throughout the growing season. Anyway, forage evaluation for increased feeding efficiency, environmental sustainability and reduced production costs has become a priority in aiding development of the farming industry.

Vallentine [7] believed that the nutrient balance of animals

Manuscript received February 14, 2013; revised April 14, 2013. This work was supported in part by the University of Malaya under Grant UMRG RP025-2012A.

The authors are with Institute of Biological Sciences, Faculty of Science, University of Malaya, 50603 Kuala Lumpur, Malaysia (e-mail: mohajer.ae@ gmail.com, rosna@um.edu.my, arash_khorasani@yahoo.com, n_mubarak1@yahoo.com). is dependent upon four basic factors including the animal's nutrient requirements and nutrient contents, digestibility and amount of feedstuffs consumed. The performance of dairy animals depends on the consistent availability of quality fodder in adequate amount. Therefore, the critical limitation on profitable animal production in developing countries is the inadequacy of quality forage [8]. Among the many options to overcome the shortage of forage, the best one is the introduction of high yielding crop varieties [9].

Assessment of the nutritive value of pastures is mainly concerned with the supply of energy, protein and minerals. Among various common chemical determinations of plant materials, $\mathrm{CP}$ and DMD are mainly considered for evaluation of forage quality [10]-[14]. Walton [15] stated that digestibility is frequently considered to be the most valuable estimate of forage quality, since it is closely associated with animal productivity. Digestibility may be related to dry matter, energy, or to any component of the nutrient material available in the feed [16].

Given the potential importance of quality in temperate forages on animal nutrition and productivity [17]-[18] in comparative forage trials would be beneficial. The current trial compared the suitability of two alternative forages, Common millet and Foxtail millet with Sainfoin for use as livestock in moderate temperature.

\section{MATERIALS AND METHODS}

\section{A. Experimental Design}

This study was carried out at the Alborz Research Center

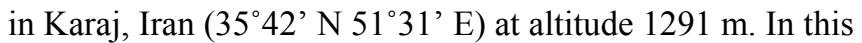
regard, nine varieties of Onobrychis sativa (E-182, H-281, K-962), Panicum miliaceum (KCM2, KCM7, KCM9) and Setaria italica (KFM1, KFM6, KFM9) germplasms existing at gene bank of natural resources were selected. The farm was equipped with a large, well-designed handling facility including many indoor and outdoor dry lot pens and pastures. Prior to this research trial, the farm was used for livestock pasture and hay production, typically with forage stands consisting of alfalfa (Medicago sativa L.), smooth brome (Bromus inermis Leyess), quackgrass (Agropyron repens L.) and alsike clover (Trifolium hybridum L.). Each plot was cultivated as long as $2 \mathrm{~m}$ of seed linearly. The distance between lines of plots was $50 \mathrm{~cm}$. Irrigation was the first made after cultivation while next irrigation was made according to the requirement of the plants. In the long run of experiment, agricultural cares including weed control and fertilizing schedule were made based on scientific advices and recommendations. 


\section{B. Traits Measurement}

After the first cut, Dry Matter (DM) yield was determined by drying the samples at $40{ }^{\circ} \mathrm{C}$ overnight (ton ha ${ }^{-1}$ ). Then it was milled well and dispatched to the laboratory for determination of nutrient value. Near Infrared (NIR) spectrometer was used for determination of dry matter digestibility, protein percentage, crude fiber, ash and acid detergent fiber percentage. After calibration of the NIR instrument, the measurement of qualitative characters was carried out following the methods of [19].

\section{Statistical Analysis}

Data was combined analyzed using as complete block design with three replications. After harvesting, data of each experiment was subjected to analysis of variance (ANOVA) separately. Duncan test method was used for determination of superior populations. Phenotypic correlations among characteristics were estimated for all pair-wise combinations. All of variables were used in principal components and cluster analysis. The variables were standardized for cluster analysis (ward method). The gathered data were analysed by using MSTATC, Minitab 16 and SAS9 software.

\section{RESULTS}

The results of ANOVA (analysis of variance) of two separate ANOVA showed that effect of species and varieties for the most traits of yield and quality factors at $1 \%$ level were significantly different (Table I).

Species of sainfoin had the highest percentage of DMD and $\mathrm{CP}$ with $68.09 \%$ and $18.15 \%$, respectively. Percentage of CF was maximum in common millet with $44.30 \%$ and foxtail millet had also high CF with and $39.57 \%$, subsequently. Although, common millet was more than foxtail millet but sainfoin had significantly the highest percentage of water soluble carbohydrates (Fig. 1). Approximately, dry matter of common millet was two and three times more than foxtail millet and sainfoin, respectively. Foxtail millet just in ADF showed the highest percentage in comparison with two other forage species (Fig. 2).

In comparing the digestibility and protein of 9 varieties, two populations of K-962 and H-281 from Onobrychis sativa had better forage quality. It became clear that variety of KCM9 from Panicum miliaceum had the highest percentage of crude fiber with $44.84 \%$ and all three varieties of Onobrychis sativa were superior in water soluble carbohydrates (Table II). The dry matter yield is one the most important studied parameters in forage crops. There were significant differences among varieties of the three species; which KCM2 of Panicum miliaceum with 18.07 ton ha-1 had the highest DM yield. Nevertheless, verities of Setaria italica had the maximum $\mathrm{ADF} \%$ and variety of KFM1 was the best with $31.29 \%$ (Table III).

The analysis results of Phenotypic dual correlations of traits have been shown based on average of three forage species results in Table IV. In the same way, correlation coefficient between DMD $\%$ with $\mathrm{CP} \%$ and $\mathrm{WSC} \%$ exhibited positive and significant difference. On contrary, dry matter yield had significantly negative relation with CP and WSC, while their association with the $\mathrm{ADF} \%$ and $\mathrm{DMD} \%$ traits were non-significant. Crude protein percentage revealed significantly negative association with $\mathrm{CF} \%, \mathrm{ADF} \%$ and $\mathrm{ASH}$ while its relation was highly positive with $\mathrm{WSC} \%$ (Table IV).

In PCA analysis, the particular values (variance) of resulting from 1 and 2 factors were more than 1 accounted for 75 and 26, 17 percent, respectively and the two first component of the PCA explained $91 \%$ of the variability observed. After varimax rotation of factors, it was determined that the first factor affected on traits of DMD\% and $\mathrm{CP} \%$, negative coefficient and $\mathrm{CF} \%$ with positive coefficient was known as quality factor. The second component was strongly correlated with dry and fresh forage yield and this component was regarded as forage yield (Table V). In cluster analysis, all traits of nine varieties were used and grouped into 3 different categories with dendrogram slice in 10.1 of Euclidean distance (Fig. 3). Dispersion of 9 varieties (in 3 clusters) based on first and second factor is shown in Figure 4. The first axis (X) was formed by $\mathrm{CP} \%$, $\mathrm{DMD} \%$ and $\mathrm{WSC} \%$ (negative coefficient) and $\mathrm{CF} \%$ (positive coefficient). Varieties of the first and second cluster were upper right, correspond to confirm low forage quality. In contrary, the Onobrychis sativa varieties were on left of $\mathrm{X}$ axis and had the highest percentage of protein, digestibility and carbohydrates. The second axis (Y) was associated with dry and fresh forage yield (positive coefficient) and ADF (negative coefficient). So, the second cluster (varieties of Panicum miliaceum) was on top of the $\mathrm{Y}$ axis with high forage yield (Fig. 4).

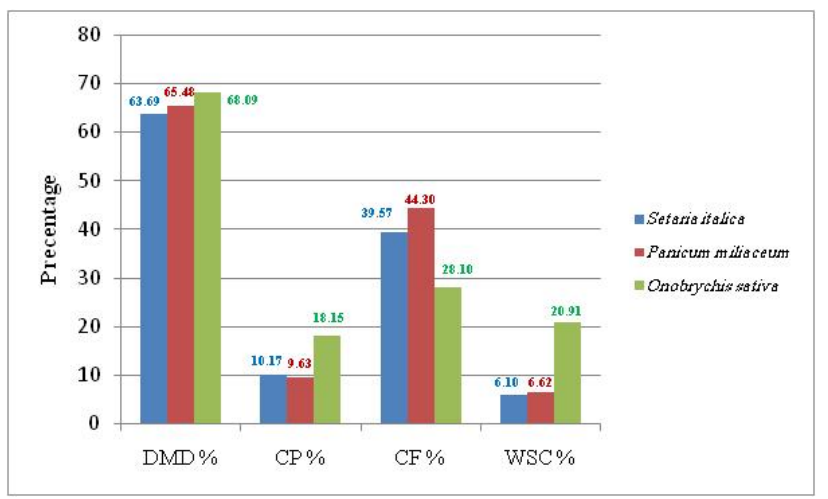

Fig. 1. Mean comparison among species; dry matter digestibility (DMD\%), crude protein $(\mathrm{CP} \%)$, crude fiber $(\mathrm{CF} \%)$, water soluble carbohydrates (WSC\%)

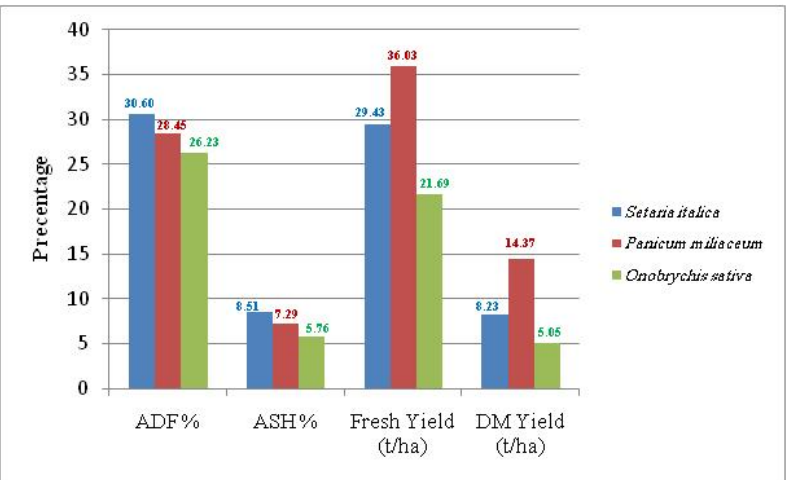

Fig. 2. Mean comparison among species in quality traits acid detergent fiber $(\mathrm{ADF} \%)$, ash (\%), dry matter yield (DM, ton ha $\left.{ }^{-1}\right)$, fresh yield (ton ha ${ }^{-1}$ ) 
TABLE I: SUMMARY OF ANOVA AND THE LEVEL OF SigNIFICANT MEAN SQUARES AMONG SPECIES AND VARIETIES

\begin{tabular}{cccccccccc}
\hline S.O.V & df & $\begin{array}{c}\text { DMD } \\
\%\end{array}$ & $\begin{array}{c}\text { CP } \\
\%\end{array}$ & $\begin{array}{c}\text { CF } \\
\%\end{array}$ & $\begin{array}{c}\text { WSC } \\
\%\end{array}$ & $\begin{array}{c}\text { ADF } \\
\%\end{array}$ & $\begin{array}{c}\text { ASH } \\
\%\end{array}$ & $\begin{array}{c}\text { Fresh Yield (ton } \\
\text { ha }^{-1} \text { ) }\end{array}$ & $\begin{array}{c}\text { DM Yield } \\
\text { (ton ha }\end{array}$ \\
\hline Species & 2 & $43.92^{* *}$ & $205.05^{* *}$ & $624.62^{* *}$ & $635.91^{* *}$ & $42.81^{* *}$ & $17.11^{* *}$ & $463.45^{* *}$ & $201.93^{* *}$ \\
Rep & 2 & 1.08 & 0.75 & 0.66 & 1.72 & 1.34 & 0.04 & 0.17 & 0.43 \\
Error & 22 & 2.92 & 2.69 & 1.97 & 2.15 & 2.30 & 0.35 & 27.45 & 5.65 \\
\hline Variety & 8 & $12.34 *$ & $55.87^{* *}$ & $157.37 * *$ & $160.92^{* *}$ & $12.58^{* *}$ & $4.92^{* *}$ & $170.83^{* *}$ & $63.46^{* *}$ \\
Rep & 2 & 1.08 & 0.75 & 0.66 & 1.72 & 1.34 & 0.04 & 0.17 & 0.43 \\
Error & 16 & 3.33 & 1.40 & 2.10 & 1.98 & 2.22 & 0.16 & 10.26 & 1.27 \\
\hline CV $\%$ & & 3.70 & 13.64 & 18.90 & 23.62 & 8.13 & 17.67 & 16.42 & 28.93 \\
\hline *
\end{tabular}

*significant at the 0.05 probability level, ** significant at the 0.01 probability level.

TABLE II: MEAN COMPARISON AMONG VARIETIES OF SETARIA ITALICA, PANICUM MILIACEUM AND ONOBRYCHIS SATIVA

\begin{tabular}{|c|c|c|c|c|c|c|c|c|c|}
\hline \multirow{2}{*}{$\frac{\text { Species }}{\text { Setaria italica }}$} & \multirow{2}{*}{$\begin{array}{l}\text { Variety } \\
\text { KFM1 }\end{array}$} & \multicolumn{2}{|c|}{ DMD \% } & \multicolumn{2}{|c|}{$\mathrm{CP} \%$} & \multicolumn{2}{|c|}{$\mathrm{CF} \%$} & \multicolumn{2}{|c|}{ WSC \% } \\
\hline & & 64.64 & $\mathrm{abc}$ & 11.66 & $\mathrm{~b}$ & 39.67 & $\mathrm{~b}$ & 5.83 & $\mathrm{~b}$ \\
\hline Setaria italica & KFM6 & 63.73 & bc & 11.03 & $\mathrm{~b}$ & 39.48 & $\mathrm{~b}$ & 5.06 & $\mathrm{~b}$ \\
\hline Setaria italica & KFM9 & 62.70 & $\mathrm{c}$ & 7.80 & $\mathrm{c}$ & 39.55 & $\mathrm{~b}$ & 7.39 & $\mathrm{~b}$ \\
\hline Panicum miliaceum & KCM2 & 65.80 & $\mathrm{abc}$ & 9.15 & $\mathrm{bc}$ & 43.45 & $\mathrm{a}$ & 7.11 & $\mathrm{~b}$ \\
\hline Panicum miliaceum & KCM7 & 65.9 & $\mathrm{abc}$ & 8.95 & $\mathrm{bc}$ & 44.61 & $\mathrm{a}$ & 7.16 & $\mathrm{~b}$ \\
\hline Panicum miliaceum & KCM9 & 64.74 & $a b c$ & 10.78 & $\mathrm{bc}$ & 44.84 & $\mathrm{a}$ & 5.58 & $\mathrm{~b}$ \\
\hline Onobrychis sativa & E-182 & 67.37 & $a b c$ & 17.51 & $\mathrm{a}$ & 29.14 & $\mathrm{c}$ & 20.22 & $\mathrm{a}$ \\
\hline Onobrychis sativa & H-281 & 68.16 & $\mathrm{ab}$ & 19.22 & $\mathrm{a}$ & 27.08 & $\mathrm{c}$ & 21.1 & $\mathrm{a}$ \\
\hline Onobrychis sativa & K-962 & 68.72 & $\mathrm{a}$ & 17.72 & $\mathrm{a}$ & 28.07 & $\mathrm{c}$ & 21.41 & $\mathrm{a}$ \\
\hline
\end{tabular}

The means of the populations with same small letters were not significantly different based on DMRT method $(\mathrm{P}<0.05)$

Dry matter digestibility (DMD\%), crude protein (CP\%), crude fiber (CF\%), water soluble carbohydrates (WSC\%)

TABLE III: MEAN COMPARISON AMONG VARIETIES OF SETARIA ITALICA, PANICUM MILIACEUM AND ONOBRYCHIS SATIVA

\begin{tabular}{|c|c|c|c|c|c|c|c|c|c|}
\hline \multirow{2}{*}{$\frac{\text { Species }}{\text { Setaria italica }}$} & \multirow{2}{*}{$\begin{array}{l}\text { Variety } \\
\text { KFM1 }\end{array}$} & \multicolumn{2}{|c|}{$\mathrm{ADF} \%$} & \multicolumn{2}{|c|}{$\mathrm{ASH} \%$} & \multicolumn{2}{|c|}{ Fresh Yield (ton ha ${ }^{-1}$ ) } & \multicolumn{2}{|c|}{ DM Yield (ton ha ${ }^{-1}$ ) } \\
\hline & & 31.29 & $\mathrm{a}$ & 8.87 & $\mathrm{a}$ & 34.00 & $a b c$ & 8.73 & $\mathrm{~cd}$ \\
\hline Setaria italica & KFM6 & 31.13 & $\mathrm{a}$ & 9.18 & $\mathrm{a}$ & 31.47 & $\mathrm{bc}$ & 9.73 & $\mathrm{c}$ \\
\hline Setaria italica & KFM9 & 29.37 & $a b c$ & 7.49 & $\mathrm{~b}$ & 22.83 & de & 6.23 & de \\
\hline Panicum miliaceum & $\mathrm{KCM} 2$ & 28.17 & $a b c$ & 7.38 & $\mathrm{~b}$ & 40.91 & $\mathrm{a}$ & 18.07 & $\mathrm{a}$ \\
\hline Panicum miliaceum & $\mathrm{KCM} 7$ & 27.68 & $a b c$ & 7.40 & $\mathrm{~b}$ & 32.30 & $\mathrm{bc}$ & 10.57 & $\mathrm{c}$ \\
\hline Panicum miliaceum & KCM9 & 29.50 & $\mathrm{ab}$ & 7.08 & $\mathrm{~b}$ & 34.86 & $\mathrm{ab}$ & 14.47 & $\mathrm{~b}$ \\
\hline Onobrychis sativa & E-182 & 26.78 & $\mathrm{bc}$ & 5.60 & $\mathrm{c}$ & 21.64 & de & 4.89 & $\mathrm{e}$ \\
\hline Onobrychis sativa & H-281 & 26.47 & $\mathrm{bc}$ & 5.85 & $\mathrm{c}$ & 17.31 & $\mathrm{e}$ & 5.14 & $\mathrm{e}$ \\
\hline Onobrychis sativa & K-962 & 25.46 & $\mathrm{c}$ & 5.84 & $\mathrm{c}$ & 26.13 & $\mathrm{~cd}$ & 5.13 & $\mathrm{e}$ \\
\hline
\end{tabular}

The means of the populations with same small letters were not significantly different based on DMRT method (P<0.05)

Acid detergent fiber (ADF \%), ash (\%), dry matter yield (DM, ton ha ${ }^{-1}$ ), fresh yield (ton ha ${ }^{-1}$ )

TABLE IV: CORRELATION ANALYSIS BETWEEN ForAGE YIELD AND QUALITY COMPONENTS ON MEAN VALUE OF THREE FORAGE SPECIES

\begin{tabular}{|c|c|c|c|c|c|c|c|}
\hline Traits & DMD \% & $\mathrm{CP} \%$ & $\mathrm{CF} \%$ & WSC \% & $\mathrm{ADF} \%$ & $\mathrm{ASH} \%$ & Fresh Yield (ton ha $\left.{ }^{-1}\right)$ \\
\hline $\mathrm{CP} \%$ & $0.75^{* *}$ & & & & & & \\
\hline $\mathrm{CF} \%$ & $-0.59 * *$ & $-0.89 * *$ & & & & & \\
\hline WSC \% & $0.68 * *$ & $0.87 * *$ & $-0.93 * *$ & & & & \\
\hline $\mathrm{ADF} \%$ & $-0.87 * *$ & $-0.59 * *$ & $0.58 * *$ & $-0.71 * *$ & & & \\
\hline $\mathrm{ASH} \%$ & $-0.64 * *$ & $-0.66 * *$ & $0.63 * *$ & $-0.82 * *$ & $0.76^{* *}$ & & \\
\hline Fresh Yield (ton ha ${ }^{-1}$ ) & -0.25 & $-0.59 * *$ & $0.76^{* *}$ & $-0.69 * *$ & 0.37 & $0.49 * *$ & \\
\hline DM Yield (ton $\mathrm{ha}^{-1}$ ) & -0.26 & $-0.60 * *$ & $0.78^{* *}$ & $-0.65 * *$ & 0.31 & 0.35 & $0.87 * *$ \\
\hline
\end{tabular}

$*$ significant at the 0.05 probability level, $* *$ significant at the 0.01 probability level. 
TABLE V: MATRIX OF COEFFICIENTS EIGEIN VECTORS AND VARIANCE PROPORTION FROM THE FIRST TWO PRINCIPAL COMPONENT AXES IN NINE VARIETIES OF THREE FORAGE SPICES

\begin{tabular}{ccc}
\hline Variable & PC1 & PC2 \\
\hline DMD \% & $\underline{\underline{\mathbf{0 . 3 5}}}$ & -0.33 \\
CP \% & $\underline{\mathbf{- 0 . 3 8}}$ & -0.01 \\
CF \% & $\underline{\underline{\mathbf{0 . 3 8}}}$ & 0.19 \\
WSC \% & $\underline{\mathbf{- 0 . 4 1}}$ & 0.05 \\
ADF \% & 0.34 & $\underline{\mathbf{- 0 . 4 2}}$ \\
Fresh Yield (t/ha) & 0.32 & $\underline{\mathbf{0 . 4 7}}$ \\
ASH \% & $\underline{\mathbf{0 . 4 8}}$ & 0.30 \\
DM Yield (t/ha) & 0.29 & $\underline{\mathbf{0 . 5 8}}$ \\
\hline Eigenvalue & 6.03 & 1.27 \\
Proportion & 0.75 & 0.26 \\
Cumulative & 0.75 & 0.91 \\
\hline
\end{tabular}

*The bold and underline coefficients have significant correlation with the relevant axes

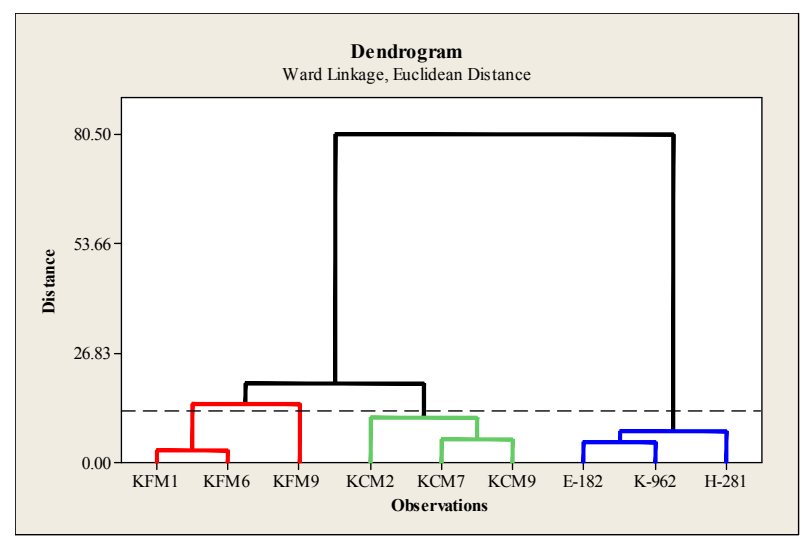

Fig. 3. Dendrogram with Ward Linkage and Euclidean Distance

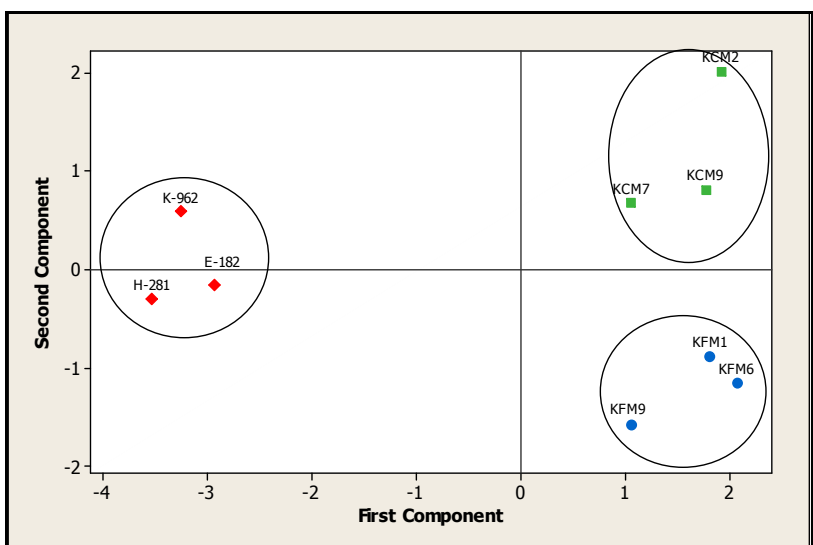

Fig. 4. Factor analysis of traits based on 3 clusters of 9 varieties of forage m spices

\section{DISCUSSION}

Plants grown at high temperatures generally produce lower quality forage than plants grown under cooler temperatures, and cool-season species grow most during the cooler months of the year. However, forage of any species tends to be lower in quality if produced in a warm region rather than a cool region. Since millets require warm temperatures for germination and development and are sensitive to frost.

The evaluation of alternative forages, specifically those containing secondary compounds for improving productivity in grazing ruminants, has recently been reviewed by Ramirez-Restrepo and Barry [20]. This review included an evaluation of chicory, birdsfoot trefoil, sulla (Hedysarum coronarium), alfalfa, white and red clover (Trifolium pratense and Trifolium repens), and perennial ryegrass (Lolium perenne), and concluded that the greatest advantages were offered by chicory, sulla, and the condensed tannin containing leguminous species birdsfoot trefoil. The current study's findings on sainfoin protein, digestibility and fiber concentrations are consistent with the literature indicating this species can provide adequate quality forage for pasture throughout the summer. The quality and nutritional value of the plant have direct relationship with their crude protein content and digestibility and reverse relationship with ADF and crude fiber. Although the relation between DM yield and $\mathrm{CP}$ was negative, however, results of DMD and CP also showed the most percentage in the sainfoin varieties where the populations had the highest forage quality. These reported correlations were similar to results of Jafari and Godarzi [21] on alfalfa.

\section{CONCLUSION}

Forage suitability evaluations revealed valuable information regarding forage establishment, yield, quality and stand persistence of sainfoin, common and foxtail millet as livestock forage. Sainfoin varieties were high in quality and low in yield in comparison with millet, but did have several harvesting well. Therefore, while useful as annual forage, it may not be suitable for perennial pasture. Although Panicum miliaceum had good forage yield, it consisted of high percentage of fiber as well. Although demonstrating positive attributes, both common and foxtail millet were generally inferior to sainfoin in quality traits, but mixtures of sainfoin with other forages, particularly millet, may prove beneficial for concentrate production in cold climates.

\section{REFERENCES}

[1] G. Chapman, E. Bork, N. Donkor, and R. Hudson, "Forage yield and quality of chicory, birdsfoot trefoil, and alfalfa during the establishment year," The Open Agriculture Journal, vol. 2, pp. 68-74, 2008.

[2] T. C. R. White, The Inadequate Environment, Springer-Verlag, Berlin, pp. 9-27, 1993.

[3] C. S. Awmack and S. R. Leather, "Host plant quality and fecundity in herbivorous insects," Annual Review of Entomology, vol. 47, pp. 817-844, 2002.

[4] P. C. Frost and J. J. Elser, "Growth responses of littoral mayflies to the phosphorus content of their food," Ecology Letters, vol. 5, pp. 232-240, 2002 .

[5] R. W. Sterner and J. J. Elser, Ecological Stoichiometry. Princeton University Press, Princeton, New Jersey, pp. 40-56, 2002.

[6] C. S. Rodrigues, M. C. T. Silveira, and D. Nascimento Júnior, "Caracterização morfogênica e estrutural de quatro gramíneas forrageiras tropicais sob crescimento livre," Reunião Annual da Sociedade Brasileira de Zootecnia, vol. 46, pp. 527-534, 2009.

[7] J. F. Vallentine, Grazing Management, Academic Press Inc.,San Diego, pp. $528,1990$.

[8] M. Sarwar, M. A. Khan, and Z. Iqbal, "Feed resources for livestock in Pakistan,” Int. J. Agric. Biol., vol. 4, pp. 186-192, 2002.

[9] M. Q. Bilal, M. Abdullah, and M. Lateef, "Effect of mott dwarf elephant grass (Pennisetum purpureum) silage on dry matter intake, milk production, digestibility and rumen characteristics in Nili-Ravi buffaloes," in Proc. 54th Annua Reciprocal Meat Conference (Vol. II). 
Indianapolis Indiana, USA, pp. 38-41, July 24-28, 2001.

[10] H. Arzani, J. Torkan, M. Jafari, and A. Nikkhah, "Investigation on effects of phenological stages and environmental factors (soil and climate) on forage quality of some important range species," Journal of Agricultural Sciences, vol. 32, pp. 385-397, 2001.

[11] H. Arzani, M. Zohdi, E. Fish, G. Zahedi Amiri, A. Nikkhah, and D. Wester, "Phenological effects on forage quality of five grass species," $J$. Range Manage, vol. 57, pp. 624-629, 2004.

[12] H. Arzani, M. R. Sadeghimanesh, H. Azarnivand, G. H. Asadian, and E. Shahriyari, "Study of phenological stages effect values of twelve species in Hamadan rangelands," Iranian Journal of Range and Desert Research, vol. 16, no. 1, pp. 86-95, 2008.

[13] C. W. Cook and J. Stubbendieck, "Range Research: Basic Problems and Techniques," Society for Range Management, Colorado, vol. 317, pp. 1986.

[14] D. J. Minson, Estimation of the Nutritive Value of Forage, J. L. Wheeler, C. L. Pearson, and G. E. Roberts, (eds), Temperate Pastures, their Production, Use and Management, Australian Wool Corporation, Collingswood, Vic., pp. 415-422, 1987.

[15] P. D. Walton, Production and Management of Cultivated Forages, Prentice-Hall, Reston, Virginia, pp. 336, 1983.

[16] P. J. V. Soest, Nutritional Ecology of the Ruminant. Cornell University Press, Ithaca, New York, pp. 137, 1982.

[17] T. N. Barry and W. C. McNabb, "The implications of condensed tannins on the nutritive value of temperate forages fed to ruminants," Br J Nutr, vol. 81, pp. 248-54, 1999.

[18] B. R. Min, T. N. Barry, G. T. Attwood, and W. C. McNabb, "The effect of condensed tannins on the nutrition and health of ruminants fed fresh temperate forages," Anim Feed Sci Technol, vol. 106, pp. 3-19, 2003.

[19] A. Jafari, V. Connolly, A. Frolich, and E. K. Walsh, "A note on estimation of quality in perennial ryegrass by near infrared spectroscopy," Irish Journal of Agricultural and Food Research, vol. 42, pp. 293-299, 2003

[20] C. A. Ramirez-Restrepo and T. N. Barry, "Alternative temperate forages containing secondary compounds for improving sustainable productivity in grazing ruminants," Anim. Feed Sci. Tech., vol. 120, no. 3-4, pp. 179-201, 2005.

[21] A. A. Jafari and A. Goodarzi, "Genetic and relationships between performance, quality and agronomic traits in 72 populations of alfalfa (Medicago sativa)," Journal of Genetics and Plant Breeding of pasture and forest, vol. 14, pp. 215-230, 2006.

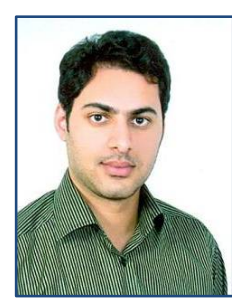

Sadegh Mohajer is a Ph.D candidate of Plant Biotechnology from Faculty of Science, University of Malaya, Kuala Lumpur, Malaysia University of Malaya.

Sadegh Mohajer received his plant breeding master from Azad University at Iran in 2008. He then was a research scientist at Iran-Levasanat Agricultural Extension Center for two years until 2010. He also was lecturer for Experimental Designs course in Payamnur University (semester 2009-10).

In 2011, he joint science faculty of the University of Malaya where he is currently student of plant biotechnology under bright spark scholarship. He has authored over 12 scientific publications and edited one book and two book chapters. He has also taken part in more than 5 international conferences.

Sadegh Mohajer has won several awards, including the 2006 first ranking of Iran Plant Breeding M.Sc. entrance examination and the best science expert at Iran-Shemiranat Agricultural Organization in 2010. He currently serves on the editorial board of; Journal of Sciencia and evaluation of some international journals such as African Journal of Biotechnology and Scientia Horticulturae. 